\title{
Articles
}

\section{Cost structures in defined contribution systems: The case of Singapore's central provident fund}

Received (in revised form): 21st February, 2008

\section{Benedict S. K. Koh}

is an associate professor of finance, and Director of the MSc in Applied Finance at the Singapore Management University. He was formerly Vice Dean of the National University of Singapore Business School. Prior to joining academia, he was a corporate banker at the Chase Manhattan Bank N.A. $\mathrm{He}$ has also published five books and numerous articles related to the topic of money management and his teaching and research interests are in corporate finance, investment management, personal finance and financial markets.

\section{Olivia S. Mitchell}

is the International Foundation of Employee Benefit Plans Professor of Insurance and Risk Management at the Wharton School, University of Pennsylvania. She recently completed an appointment on the Advisory Board for the Singapore Central Provident Fund and has served as a visiting professor at the Singapore Management University. Her main areas of interest are private and public insurance, risk management, public finance and labour markets, and compensation and pensions with both an American and an international focus.

\section{Joelle H.Y. Fong}

is currently a doctoral candidate in the Department of Insurance and Risk Management at The Wharton School, University of Pennsylvania. She has an MSc in Applied Finance from the Singapore Management University and a Bachelor in Accountancy (Honors) from Nanyang Technological University. She is also a CPA and worked in various government agencies within the Singapore Civil Service for six years prior to pursuing her doctoral studies. Her research interests are in pensions, risk management, finance and public policy.

\begin{abstract}
Retirement systems are increasingly asked to do an ever-better job of enhancing the performance of pension investments. The Singaporean Central Provident Fund permits pension system participants to keep their money in a government-run investment pool, or if they wish, they may select professionally managed unit trusts for their retirement accumulations. Opting for investment choice also exposes members to additional investment costs not charged by the government-managed account. This paper explores the charges levied by the private fund managers and we show that foreign ownership, active style of management and equity/balanced funds tend to be most expensive. We conclude with a discussion of policy options available to reduce retirement system costs.
\end{abstract}

Pensions (2008) 13, 7-14. doi:10.1057/pm.2008.3

Keywords: pension, retirement, investment, portfolio, investment choice, expenses

\section{Introduction}

Established in 1955 as a mandatory saving programme, Singapore's Central Provident Fund (CPF) has grown into a mature social insurance scheme covering more than 3 million members. Inasmuch as CPF assets represent a sizeable

Correspondence: Joelle H.Y. Fong, Department of Insurance and Risk Management, The Wharton School, 3620 Locust Walk, St 3000 SHDH, Philadelphia, PA 19104-6320, USA.

Tel: +1 215898 0424;

Fax: +1 2158980310 ;

E-mail: hfong@wharton.upenn.edu portion of household assets, it is essential that these savings be invested as efficiently as possible. This paper explores the determinants of fees and charges associated with investing in the funds allowed by the CPF and offers some thoughts about how to make this nationally defined contribution system more cost-effective.

\section{A brief overview: The Singaporean CPF scheme}

Initially, the CPF required contributors to hold all their money in a government-managed fund; 
more recently, however, the system has permitted participants to diversify the assets by holding some of their money in capital market-based accounts. ${ }^{1,2}$ Thus in 1986 the Board introduced an Approved Investment Scheme, followed in 1994 by a longer list known as the CPF Investment Schemes (CPF-IS). As a result of this process, participants have long been permitted to hold unit trusts and investment-linked insurance products (ILP). ${ }^{3}$ It is interesting, however, that today most CPF saving is still held in the 'default' government-managed interest rate-guaranteed ordinary account (OA) and special account (SA) earning 2.5 and 4 per cent per year, respectively. For instance, only about one-fifth (28 per cent) of available funds has been tapped for investment outside the government's CPF fund, with most of this held in insurance policies; the remainder is split between direct stock holdings and mutual funds or unit trusts. 4,5

It might be thought that unit trust investments would be attractive to CPF members because they offer investors diversification and liquidity, as well as access to regional bourses. On the other hand, observers have suggested that investors may be held back by performance inconsistency of unit trust fund managers. ${ }^{6}$ Another problem may be that participants simply do not know what to invest in and how to invest. There are 231 different unit trusts currently on offer with a daunting array of fees and charges and layers of costs; in such an environment, members may hesitate to hand over their retirement savings. ${ }^{7}$ Thus, wary investors may select the path of least resistance - which in this case would be to leave their saving in the default government-managed and interest-rate-guaranteed CPF accounts. In what follows, we describe the range of fees and charges, and outline their structure and impact.

\section{Sales charges, fees and transactions costs for CPF-IS investors}

Table 1 illustrates the range of fees and charges facing a prospective investor of unit trusts in Singapore. Focusing first on initial sales charges for unit trusts, these range from 0 to 5 per cent of the initial amount invested and are typically reflected in the bid-offer spread. ${ }^{8}$ Accordingly, sales charges constitute a hefty portion of the overall costs of investment and can have a significant impact on the net return from retirement savings invested. In practice most fund distributors in Singapore report only having an initial sales charge, which is consistent with the fact that the Investment Management Association of Singapore (IMAS) ${ }^{9}$ reports only the initial charge ${ }^{10}$ for each permissible unit trust. Many other fees and charges also apply to CPFISincluded funds. The initial sales charge plus the transaction charge on purchase would be equivalent to a front-end sales load in the US context; the realisation charge would be the equivalent of a back-end sales load. Most of the

Table 1: Sales charges and direct fees payable by CPF-IS scheme investors

\begin{tabular}{ll}
\hline Fees payable & Description \\
\hline $\begin{array}{l}\text { Initial sales charge } \\
\text { (equivalent of 'front-end } \\
\text { load') }\end{array}$ & $\begin{array}{c}\text { Also called the preliminary charge. This is payable by investors upon purchase of units in the } \\
\text { fund and is retained by the fund managers. } \\
\text { The majority of CPFIS-included unit trusts have an initial sales charge ranging from } 0 \text { to } 6 \% .\end{array}$ \\
$\begin{array}{l}\text { Transaction charge on } \\
\text { purchase }\end{array}$ & $\begin{array}{r}\text { This refers to any transaction cost charged by the underlying funds of the unit trust but not paid } \\
\text { or absorbed by the unit trust. This is payable by investors. } \\
\text { Very few unit trusts currently charge this cost component. }\end{array}$ \\
$\begin{array}{l}\text { Realisation charge } \\
\text { (equivalent of 'back-end } \\
\text { load') }\end{array}$ & $\begin{array}{r}\text { This is payable by investors upon either full or partial realisation of the units in the fund and is } \\
\text { The majority of CPFIS-included unit trusts currently waive the realisation charge except for a } \\
\text { handful of funds that charge 1\%. Regardless, it is noted that all unit trusts specify a maximum } \\
\text { charge provision in their prospectuses. }\end{array}$ \\
This fee is payable by investors on shares redeemed within a specified time period (eg 90 days). \\
This is usually imposed by the unit trust to discourage short-term trading. \\
Also called the conversion charge. This fee is imposed on investors when they switch between \\
share classes or funds. This fee, however, may sometimes be waived by the fund administrator.
\end{tabular}

Source: Authors' summary based on fund prospectuses. 
unit trusts now levy only the initial sales charge, although many state in their prospectus that they reserve the right to levy a 1 per cent realisation charge. For unit trusts invested in underlying sub-funds, the underlying sales charges (when applicable) are borne by the unit trust and not charged directly to investor. Other costs of investing into the underlying sub-funds not borne by the unit trust may be levied on investors as a 'transaction charge on purchase'. Also when moving out of a fund, an investor must often pay a redemption fee for short turnaround periods (eg 90 days or fewer). A switching fee will usually also be imposed on investors only when they switch between share classes or funds; in some instances, this fee may be waived by fund administrators.

Currently, one must ferret through hundreds of individual fund prospectuses to ascertain expenses beyond the initial sales charge; few investors would thus be able to compare easily the total costs of buying, owning and selling different unit trusts. A simpler approach might be to ask the funds to develop a comparable figure called the 'sales load', which would combine all initial sales charges, transaction charges on purchase and realisation charges assuming a standardised holding period for each type of investment. This might stop unsophisticated investors from relying only on initial sales charges reported by fund distributors and allow investors to see the sale charges over comparable holding periods.

Investors in CPFIS-included unit trusts also may have to pay transaction fees to agent banks and fund distributors that depend on the source of the money being invested. For instance, those wishing to invest $\mathrm{OA}$ monies must open a $\mathrm{CPF}$ Investment Account with an agent bank, which is the key financial intermediary ${ }^{11,12}$ under the CPFIS-OA. These agent banks then liaise with the CPF Board and the product providers to settle investor trades and help track investment holdings. By contrast, investing in the CPFIS-SA accounts does not incur these charges as the CPF Board liaises with the product providers directly. Accordingly, transaction fees are higher for OA than for SA saving, due to the role of agent banks.

Table 2 shows the agent bank fees applicable under the CPFIS-OA. These include a transaction fee for buy, sell and switching ${ }^{13}$ transactions, as well as a quarterly service charge of minimum $\$ 2-5$ collected by the agent bank for servicing each active CPF Investment Account. The actual quantum of agent bank fees paid may differ further, depending on whom the investor transacts with: whether a traditional distributor or an investment administrator.

In addition to sales charges and fees paid by investors, unit trusts also are subject to a wide

Table 2: Cost structures of fund distributors and IAs for CPFIS-included unit trusts

\begin{tabular}{|c|c|c|}
\hline & $\begin{array}{l}\text { If purchased through a distributing bank or } \\
\text { online distributor (nonwrap account structure) }\end{array}$ & $\begin{array}{l}\text { If purchased through an Investment Administrator (IA) } \\
\text { (wrap account structure) }\end{array}$ \\
\hline \multicolumn{3}{|c|}{ Agent bank's fees (Under CPFIS-OA) } \\
\hline Transaction fee & $\begin{array}{l}\text { Between } \$ 2.00 \text { and } \$ 2.50 \text { per lot, subject to } \\
\text { a maximum between of } \$ 20 \text { and } \$ 25 \text { per } \\
\text { transaction. }\end{array}$ & $\$ 2-\$ 2.50$ per transaction. \\
\hline Service charge & $\begin{array}{l}\$ 2.00 \text { per unit trust fund per quarter, subject to } \\
\text { a minimum of between } \$ 2 \text { and } \$ 5 \text {. }\end{array}$ & $\begin{array}{l}\$ 2.00 \text { per wrap account per quarter, subject to a } \\
\text { minimum of between } \$ 2 \text { and } \$ 5 \text {. }\end{array}$ \\
\hline \multicolumn{3}{|c|}{ Other charges (Under CPFIS-OA \& CPFIS-SA) } \\
\hline Sales charge & $\begin{array}{l}\text { Between } 0 \text { and } 5 \% \text { (reflected in the bid offer } \\
\text { spread) of initial amount invested. }\end{array}$ & Between 0 and $6 \%$. \\
\hline Annual wrap fee & - & Up to $1.5 \%$ of the value of the investor's holdings \\
\hline Switching fee & $\begin{array}{l}\text { Between } 0 \text { and } 5 \% \text { (reflected in the bid offer } \\
\text { spread). }\end{array}$ & Nil or as agreed by the member and his financial advisor \\
\hline Other fees & - & $\begin{array}{l}\text { Annual establishment fee of up to } 1.56 \% \text { with a } \\
\text { chargeable exit fee (for first five years) under the } \\
\text { 'deferred sales charge' option. }\end{array}$ \\
\hline
\end{tabular}

Source: http://mycpf.cpf.gov.sg/Members/Gen-Info/Faq/Investment/INV.htm\#app4. 
Table 3: Treatment of various fund expenses in computing the total expense ratio

\begin{tabular}{ll}
\hline Expenses to be included & Expenses to be excluded \\
\hline - Management fee & - Interest expense \\
- Trustee fee & - Brokerage and other transaction costs \\
- Administration fee & - Foreign exchange gains and losses (both realised and unrealised) \\
- Accounting and valuation fees & - Tax (deducted at source, on income received, withholding tax) \\
- Registrar fees & Front-end, back-end loads and other costs arising on the purchase or \\
- Legal and professional fees & - Dividends and other distributions paid to unit-holders \\
- Printing \& distribution & - Insurance charges (for ILP funds only) \\
- Audit fees & - All marketing, promotional and advertising expenses incurred in \\
- Amortised expenses & relation to the Fund \\
- GsT on expenses & \\
- Operating costs incurred at parent level (for & \\
- - Operating costs incurred by underlying target & \\
- fund(s) which unit trusts invest into & \\
- Performance-related fee (if included, must be & \\
$\quad$ disclosed. A separate expense ratio excluding & \\
$\quad$ this remuneration should also be disclosed.) & \\
\hline
\end{tabular}

Source: Derived from IMAS Guidelines for the disclosure of expense ratios, revised 25th May, 2005, www.imas.org.sg/downloads/ imas/IMAS_Revised_Guidelines_on_Expense_Ratio.pdf.

range of management, trustee, administration, custodian, registrar, audit, accounting and valuation, and other fees. ${ }^{14}$ These are paid by unit trusts directly, but of course they are passed on to investors inasmuch as such expenses reduce the net return paid on CPF investments. To inform consumers about operating expenses charged to unit trusts, which of course influence net returns, IMAS has developed an aggregate measure called the total expense ratio to capture a fund's operating expenses expressed as a percentage of that fund's average $\mathrm{NAV}^{15}$ over a given time period. The aim is to create a level playing field, so investors may be properly informed of the costs of having their funds managed and also to enable meaningful comparison across funds with different cost structures. ${ }^{16}$

Table 3 summarises the expense ratios or annual fund operation charges for CPFISincluded unit trusts, which range from 0 to 7.1 per cent of NAV. This range is rather wide, perhaps because fund administration fees differ so much: as an example, the annual management fee component alone varies between 0 and 3 per cent of NAV. ${ }^{8}$ Another possible reason for the variation might be that there is no mechanism for investors to verify the accuracy of these publicly reported expense ratios. ${ }^{17}$

\section{What drives differences in fund costs?}

To examine the links between costs and fund characteristics, we have compiled the fees and charges of CPFIS-included unit trusts from individual fund prospectuses, covering virtually all aspects of costs. This results in a sample of 235 unit trusts representing 97 per cent of the CPFIS-included unit trusts (as of 30 June 2006). This data set includes a wide range of unit trusts characteristics such as size, age, type and ownership. For analysis purposes, the following aspects of each fund are worthy of examination:

- Fund size, or value of assets under management.

- Age of fund, or years since launch date.

- Fund ownership indicating (a) whether the unit trust is managed by a foreign or domestic (Singaporean) fund management company and, (b) whether the fund management company is bank-related or not.

- Style of fund management, or whether the unit trust is actively managed or a passive indexed fund.

- Type of fund, namely whether it was an equity, balanced, income or cash fund. 
Table 4: Summary data on costs by fund descriptor

\begin{tabular}{|c|c|c|c|c|}
\hline Risk category & Type of fund & \#Funds & $\begin{array}{l}\text { Average sales } \\
\text { load (\%) }\end{array}$ & $\begin{array}{l}\text { Average expense } \\
\text { ratios (\%) }\end{array}$ \\
\hline Higher risk & Equity & 167 & 4.9 & 2.07 \\
\hline Medium-high risk & Balanced & 26 & 4.8 & 1.93 \\
\hline Low-medium risk & Income & 39 & 2.1 & 1.12 \\
\hline Lower risk & Cash & 3 & 0.1 & 0.71 \\
\hline Total & & 235 & & \\
\hline \multicolumn{5}{|c|}{ Panel B: Costs of active vs. passive CPFIS-included unit trusts } \\
\hline & $\begin{array}{l}\text { Number of } \\
\text { funds sampled }\end{array}$ & $\begin{array}{l}\text { Average sales } \\
\text { loads (\%) }\end{array}$ & $\begin{array}{l}\text { Average management } \\
\text { fee (\%) }\end{array}$ & $\begin{array}{l}\text { Average expense } \\
\text { ratio (\%) }\end{array}$ \\
\hline Equity funds & 167 & 4.9 & 1.4 & 2.1 \\
\hline Active & 164 & 5.0 & 1.4 & 2.1 \\
\hline Passive & 3 & 2.1 & 0.7 & 1.0 \\
\hline Balanced funds & 26 & 4.8 & 1.3 & 1.9 \\
\hline Active & 22 & 5.0 & 1.3 & 2.1 \\
\hline Passive & 4 & 3.5 & 1.0 & 1.3 \\
\hline Income funds & $39^{a}$ & 2.1 & 0.9 & 1.1 \\
\hline Cash funds & 3 & 0.1 & 0.5 & 0.7 \\
\hline Sample mean & & 4.4 & 1.3 & 1.9 \\
\hline \multicolumn{5}{|c|}{ Panel C: Analysis of costs by fund ownership } \\
\hline & Domestic (\%) & Foreign (\%) & Difference (\%) & \\
\hline Average sales load $(A)$ & 3.86 & 4.66 & 0.80 & \\
\hline Average management fee & 1.17 & 1.39 & 0.22 & \\
\hline Average expense ratios (B) & 1.62 & 2.04 & 0.42 & \\
\hline Average first-year total cost $(A+B)$ & 5.48 & 6.70 & 1.22 & \\
\hline
\end{tabular}

Source: Authors' computations using fund prospectuses and IMAS-reported expense ratios as at 30th June, 2006.

${ }^{a}$ There is one partially passive fund under the income funds category. Its costs are, however, not presented separately since one single fund is not a representative sample for analysis.

It is useful to classify CPF-IS funds into four risk categories based on their level of equity risk. As Table 4 shows, most funds are either in the medium-to-high or higher risk categories, ${ }^{18}$ with 82 per cent either pure equity or balanced funds with much higher average sales loads of around 5 per cent, vs the 2.1 per cent for income and 0.1 per cent for money market funds (panel A). This may be explained by the higher monitoring and fund administration costs associated with equity and balanced funds, although some of the cost differential may arise from these 193 funds having to compete for individual investors' attention. Regarding fund management style, panel B shows that passive funds are less expensive to manage than actively managed funds, with sales loads less than half the sample mean; their management fees average 46 per cent below and expense ratio 45 per cent below the respective sample means. Even within balanced funds, passively managed entities enjoy lower costs than actively managed ones but the differences are smaller.

Next we turn to fund ownership, where it might be thought that unit trusts offered by foreign entities might be more expensive due to higher administrative costs associated with the need to advertise and compete in the Singapore marketplace, compared to domestically-run funds (especially the three local banks with a home advantage). On the other hand, foreign unit trusts may be less expensive as they are almost ten times larger in terms of asset size, so might translate economies of scale into lower fees for investors. Panel $\mathrm{C}$ indicates that the first effect dominates, as the funds offered by foreign entities appear somewhat more expensive, with the sales load and 
Table 5: Regression estimates of determinants of CPF-IS unit trust loads and costs (standard errors in parentheses)

\begin{tabular}{|c|c|c|c|}
\hline \multirow[t]{2}{*}{ Explanatory variable } & \multicolumn{3}{|l|}{ Dep. variables } \\
\hline & Sales loads $\mathbf{a}(1)$ & Management fee (2) & First-year total costs (3) \\
\hline $\begin{array}{l}\text { Fund size (Ln S\$m) } \\
\text { Age of fund }\end{array}$ & $\begin{array}{l}0.030(0.033) \\
0.011(0.010)\end{array}$ & $\begin{array}{l}-0.007(0.012) \\
-0.004(0.004)\end{array}$ & $\begin{array}{c}-0.077^{\star \star}(0.039) \\
0.002(0.012)\end{array}$ \\
\hline $\begin{array}{l}\text { Ownership of fund } \\
\text { Foreign-owned (vs domestic) }\end{array}$ & $0.417^{\star \star}(0.190)$ & $0.161^{\star \star}(0.070)$ & $0.531^{\star \star}(0.224)$ \\
\hline $\begin{array}{l}\text { Fund style } \\
\text { Active (vs passive) }\end{array}$ & $1.357^{\star \star}(0.307)$ & $0.411^{\star \star}(0.113)$ & $2.015^{\star \star}(0.363)$ \\
\hline $\begin{array}{l}\text { Fund management company } \\
\text { Bank-related (vs nonbank) }\end{array}$ & $0.031(0.183)$ & $0.065(0.067)$ & $-0.203(0.217)$ \\
\hline $\begin{array}{l}\text { Type of fund } \\
\text { Equity (vs income) } \\
\text { Balanced (vs income) } \\
\text { Cash (vs income) }\end{array}$ & $\begin{array}{r}2.653^{\star \star}(0.147) \\
2.784^{\star \star}(0.208) \\
-2.060^{\star \star}(0.482)\end{array}$ & $\begin{array}{r}0.522^{\star \star}(0.054) \\
0.427^{\star \star}(0.077) \\
-0.357^{\star \star}(0.178)\end{array}$ & $\begin{array}{r}3.576^{\star \star}(0.174) \\
3.631^{\star \star}(0.246) \\
-2.443^{\star \star}(0.571)\end{array}$ \\
\hline $\begin{array}{l}\text { F Statistic } \\
R^{2}\end{array}$ & $\begin{array}{l}64.723(0.000) \\
0.696\end{array}$ & $\begin{array}{l}19.214(0.000) \\
0.405\end{array}$ & $\begin{array}{l}83.213(0.000) \\
0.747\end{array}$ \\
\hline
\end{tabular}

Notes: ${ }^{\star}$ Coefficient statistically significant at the 5 per cent level.

Source: Authors' computations using fund prospectuses and IMAS-reported expense ratios as at 30 June 2006.

aSales loads include the front-end loads (initial service fee and transaction charge on purchase) and the back-end load (realisation charge).

expense ratio of foreign funds respectively exceeding the domestic funds' by about 80 and $42 \mathrm{bp}$. This implies that the first-year total $\operatorname{cost}^{19}$ of a foreign fund would average $122 \mathrm{bp}$ (or 1.22 per cent) more than a domestic fund. It might be that domestic funds charge less on the IS accounts to the extent they can cost-recover via cross-selling in other product lines. Therefore, investors would do well to attend to the entire spectrum of costs across financial products rather than simply focusing on a single cost component.

Another possible determinant of costs may be the size of fund: for instance as assets under management rise, one might expect scale economies. ${ }^{20,21}$ To verify whether fund size has an impact on cost of unit trusts in the CPFIS context, we split the sample into ten asset deciles where we found that most CPF-IS unit trusts (219 of 235) are quite small with an aggregate value of assets managed at under $\$ \$ 500 \mathrm{~m}$.

Somewhat unexpectedly, we find that sales loads and management fee do not appear to be related to fund size. This may be because, although there are many unit trusts, these are offered by a small set of fund management companies; the industry is rather concentrated.

To further explore the determinants of sales loads and annual operating expenses of the CPFIS unit trusts, we run regressions of unit trust costs on the key characteristics just described as follows:

$$
\begin{aligned}
C_{i}= & \alpha_{0}+\alpha_{1} \ln \left(\operatorname{size}_{i}\right)+\beta_{1} D_{1}+\beta_{2} D_{2}+\beta_{3} D_{3}+\beta_{4} D_{4} \\
& +\beta_{5} D_{5}+\beta_{6} D_{6}+\varepsilon_{i}
\end{aligned}
$$

where $C_{i}$ refers to the percent cost of the unit trust (in bps); $\ln \left(\right.$ size $\left._{i}\right)$ refers to the natural $\log$ of fund assets; and $D_{1}-D_{6}$ refer to fund characteristics such as foreign ownership, active fund style, bank-related fund and types of fund. We use three different definitions of costs in Table 5: sales loads (Column 1), annual management fees (Column 2) and first-year total costs (Column 3). Of all the unit trust characteristics considered, style of fund management, ownership and type of fund are the factors most strongly associated with the cross-sectional variation in costs. Holding other things constant, activelymanaged unit trusts charge $136 \mathrm{bps}$ more in sales 
loads than passive funds, higher management fees of $41 \mathrm{bps}$ and first-year total costs of $202 \mathrm{bps}$. Foreign-owned funds charge $42 \mathrm{bps}$ more sales load than locally owned funds, 16 bps more management fees and 53 bps more in total firstyear costs. Equity and balanced funds also levy higher sales load and management fees than do income funds, while money market fund charge much less. Table 5 also shows that size of fund is significant in explaining the differences in first-year total cost of unit trusts but not the sales load and management fee. Larger funds charge 8 bps less in total costs than smaller funds. Other variables examined such as the age of the fund and bank affiliation do not significantly account for sales loads and management fee differences.

\section{Discussion and conclusion}

Koh et al. ${ }^{4}$ showed that most CPF pensioners have not actively opted from the menu of investment options available in the CPF-IS scheme in their quest to build retirement or saving accounts. They suggested that this is because the 'default' return paid to those who keep their money in the CPF is deemed to be a rather high riskless rate. This paper suggests that another possible explanation may be that CPFIS funds levy a rather bewildering range of sales charges, transactions fees, portfolio management costs, fund administration expenses and other miscellaneous costs. Searching through individual fund prospectuses to ferret out all these expenses is difficult, and some CPFIS investors may not be readily able to assess and compare total costs of buying, owning and selling different unit trusts. Being perplexed and risk averse, members may choose the path of least resistance.

As the CPF investment scheme evolves, it may be worth exploring further how to formalise a means of combining the initial sales charge, transaction charge on purchase and realisation charges in a single measure called the sales load. This measure would allow investors to see the sale charges in their entirety should they decide to buy into a unit trust now and exit at a later point in time. This information could readily be displayed in a web-based calculator showing, for each fund, the component costs as well as all-in costs over varying holding periods.

In Singapore, those who invest their retirement saving in the private market pay rather high transaction costs for the privilege of accessing the capital market directly. One reason is that participants tend to favour medium to high-risk funds, which are the equity and balanced funds, and these are more costly than the income and money market funds. These are also the most numerous, comprising 80 per cent of the total funds on offer, and the fraction has been surprisingly constant over time despite the rapid growth in number of funds offered over time. While these may also earn higher returns, the higher expense threshold is substantial. A related fact is that Singapore's CPF-IS has rather few passively managed funds, and very few target maturity date or lifecycle funds that automatically rebalance participants' investments as they age. These latter funds tend to appeal to novice investors, and they have recently been allowed as the default investment for US pension investors. Further standardisation of investment costs would likely help consumers better evaluate how well their investments might do, particularly given the various loads, asset-based and fixed charges, and wrap fees expressed in different terms and reported in different locales, varying with the specific product in question.

Disclaimer: Opinions and views remain those of the authors, and not those of the institutions to which they are affiliated.

\section{References and Notes}

1 Low, L. and Aw, T. C. (1997) 'Housing a Healthy, Educated, and Wealthy Nation through the CPF', The Institute of Policy Studies, Times Academic Press, Singapore.

2 CPF (2007a) 'Asset Enhancement: CPF Investment Scheme How it Works', Central Provident Fund Board, http://mycpf. cpf.gov.sg/Members/Gen-Info/FAQ/investment/CPFInvscheme.htm, viewed March 2007.

3 In Singapore, unit trusts (also known as collective investment schemes) refer to professionally managed funds offered by fund management companies. The unit trusts may have different investment objective, styles of management and different levels of equity risk depending on their portfolio allocation. This is unlike the US where a unit investment trust generally refers to 
a fixed, unmanaged portfolio of income-producing securities. Shares in the trust are sold to investors who received capital gains, dividend payments and interest at regular periods. A unit investment trust is typically considered a low-risk, low-return investment. Unit trusts in Singapore are more comparable to mutual funds in the US.

4 Koh, B. S. K., Mitchell, O. S., Tanuwidjaja, T. and Fong, J. (2007) 'Investment patterns in Singapore's central provident fund system', Pension Research Council Working paper, The Wharton School, February.

5 Another $\$ 79 \mathrm{bn}$ is held in the investment saving scheme but has not been actively invested.

6 Chai, N. C., Chua, S. T. and Tsui, A. K. (2007) 'Central provident fund investment scheme in Singapore: A preliminary comparison of returns', Department of Economics, National University of Singapore. Working Paper presented at the 15th Australian Colloquium of Superannuation Researchers, July.

7 CPF (2007e) 'Performance and Risk Monitoring Report for Unit Trusts Q4 2006', Standard \& Poor's Fund Services, Asia, February, http://www.imas.org.sg/downloads/imas/CPFIS_ Performance_Q4_2006_2202.pdf.

$8 \mathrm{CPF}$ (2007c) 'CPF Investment Scheme - Annex D: Charges Typically Incurred for Various Investments', Central Provident Fund Board, http://mycpf.cpf.gov.sg/Members/Gen-Info/FAQ/ Investment/INV.htm, viewed March 2007.

9 Investment Management Authority of Singapore (IMAS; 2007) (2007) 'Fund Information Service for CPFIS-Included Unit Trusts \& Investment-Linked Insurance Products', IMAS and Life Insurance Association of Singapore, http://www.fundsingapore. com, viewed 6th November-7th March.

10 A comparison of the online data with figures in fund prospectuses shows that the 'initial charges' reported by IMAS may refer to the initial sales charge or the sum of sales charges. For instance, IMAS includes the realisation charge in the 'initial charges' reported for five funds but omitted it for one fund (as of 12/06). In another case, the 'initial charges' reported included a transaction charge on purchase.

11 The agent banks are appointed to maintain members' CPF Investment Accounts under the CPFIS-OA as they have an extensive network of branches and facilities to support the investment and settlement of shares and bonds listed on the Singapore Exchange. The agent banks' electronic banking services such as ATMs are easily accessible and allow members to conveniently apply for shares or bonds during an IPO. The banks are also able to handle the complex processing of corporate actions such as bonus and rights issues, dividend payments and schemes of arrangement under the CPFIS-OA ${ }^{12}$.
$12 \mathrm{CPF}(2007 \mathrm{~b})$ 'CPF Investment Scheme - Investing For the First Time', Central Provident Fund Board. http://mycpf.cpf. gov.sg/Members/Gen-Info/FAQ/Investment/INV.htm, viewed March 2007.

13 A switching transaction will involve a buy transaction plus a sell transaction.

14 Other fees include service fee, asset allocation fee, legal fee, printing fee and distribution fee.

15 The NAV of a unit trust is the value of the unit trust fund's assets less its liabilities.

16 IMAS (2005) 'Revision to Guidelines on Calculation of Expense Ratio and IMAS Guidelines for the disclosure of expense ratios', Investment Management Association of Singapore, 25th May. www.imas.org.sg/downloads/imas/IMAS_ Revised_Guidelines_on_Expense_Ratio.pdf.

17 Expense ratios are furnished by fund management companies and insurers. These ratios are made available to the public through the quarterly Performance and Risk Monitoring Reports for CPFIS-included funds published by Standard \& Poor/Morningstar and are also be found on IMAS website. These expense ratios are supposed to be calculated according to IMAS latest guidelines.

18 Mercer Investment Consulting, CPF Board's consultant, developed a risk classification system for the CPFIS that assigns various risk levels to permitted investments. The unit trust or ILP with a greater proportion of its assets invested in the more volatile stock market will have a higher equity risk. Based on its level of equity risk, the unit trust or ILP will be assigned one of the four risk categories.

19 The 'first-year total costs' figure computed in this study is derived by adding average sales load to the average expense ratio. Two points are worthy of further note. (i) Although the average load is expressed as a percent of the amount invested and expense ratio is expressed as a percent of the average $\mathrm{NAV}$, these bases should more or less be equal as long as the fund is not growing rapidly. (ii) A more precise way to compute 'first-year total costs' might be to convert the sales load into an annualised load to align it with annual expense ratio component.

20 Bateman, H. and Mitchell, O. S. (2004) 'New evidence on pension plan design and administrative expenses', Journal of Pension Finance and Economics, Vol. 3, No. 1, pp. 63-76.

21 Mitchell, O. S. (1998) 'Administrative costs of public and private pension plans', in Feldstein, M. (ed.) 'Privatizing Social Security', NBER. Chicago: University of Chicago Press, pp. 403-456. 